\title{
Religion in the Curriculum in the Post-Modern Era: Why Young People Should Know about Religion?
}

\author{
Marios Koukounaras-Liagis \\ Lecturer in Religious Education at University of Athens, faculty of Theology
}

\begin{abstract}
In this paper the author presents research into the role of religion in the modern world and attempts to answer the question why students should know about religion, and particularly why religion should be taught in schools. He also presents research into young people's perspectives on the role of religion in European school systems while at the same time offering a justification for compulsory Religious Education. The arguments are based on international and European legislation, experiences of different countries and the findings of two different researches in Greece published for the first time. Furthermore, the author offers a proposal for compulsory Religious Education which is necessarily based on the constructivist theory according to pedagogical practice in Europe. Finally, the paper stresses the existence of the right to withdraw from Religious Education and the author illustrates the consequences of such a practice.
\end{abstract}

\section{Introduction}

In recent years there has been a fruitful conversation about religious education (hereafter referred to as RE) and whether or not it should be a compulsory discrete subject within the curriculum. This topic reflects the actual contradiction between ongoing secularization and religion which continues to enjoy global significance for humankind. Taking into account the arguments of both sides we argue for a consensus on the aims and purposes of RE that makes the subject of RE indispensable to a contemporary curriculum that helps students to cope with the world they live in, and one in which religious practices and beliefs need to be comprehended. We are of course talking about a subject in the school curriculum whose purpose is not only to embrace different religions, beliefs and religious phenomena but also one which is attended by all the students regardless of their beliefs or nonbeliefs.

\section{Religion and education in the modern world}

Since the Enlightenment many people have always expected that, as the Western nations developed and secularized, this process labeled secularization would mean that religion would decline in significance as an influence in the modern world. Despite this expectation religion persisted and continues to influence the public sphere in Europe and to be an important factor in human affairs universally. Peter Berger confessed 40 years ago "The big mistake, which I shared with almost everyone who worked in this area [sociology of religion] in the $1950 \mathrm{~s}$ and $60 \mathrm{~s}$, was to believe that modernity necessarily leads to a decline in religion...Modernity, as has become increasingly clear, is not necessarily linked to secularization" [1]. $\mathrm{He}$ was the first to speak about the "desecularization" of the world [2] and tried to stress that the scientific study of religion must bracket the ultimate truth claims implied by its subject [3]. Needless to say most scientists, such as Bellah, Geertz and Luckmann, define religion in terms of its social or psychological function and mainly avoid refering to the Islamic world when they advocate secularisation. Furthermore when they are concerned with Eastern cultures they have the secularised Western point of view engendered by the study of Eastern cultures, in contrast to Edward Said and Orientalism which offered a critical analysis of the cultural ideas and concepts that are the bases of the study of cultures of the Eastern part of the world [4]. Obviously what aforementioned defines is that the actual impact of religion on public life is a central concern.

Nowadays there are two simultaneous realities. Consider, on the one hand, the demise of metaphysics in philosophy, the predominance of the scientific method as the means to knowledge, the extinction of any form of religious cosmology and the important impact of the theory of evolution and, on the other hand, the institutional influence of religion in Europe, the re-election of the president of The United States in November of 2004 whose victory was attributed to the strength of religious factors influencing the way Americans voted and Islamic values which seem to have influenced different political events since the 1979 Iranian revolution onwards [5]. With the demise of the Soviet bloc and consequently the end of the Cold War, the fall of the Berlin Wall, the deposition of the Shah in Iran and the subsequent events in the Middle East, Iraq and Afghanistan, religion has been brought by globalization firmly back onto the agenda [6]. 
Who hasn't heard about the fierce Muslim reaction to the Danish cartoons in 2005 or more recently, this year, about the reactions to the American Baptist pastor's suggestion of rounding up the homosexuals and putting them in a concentration camp? And more recently the Muslim reaction to the American film about the Prophet Muhammad? As Andrew Wright argues, "it is virtually impossible to make sense of the culture and politics of the present age without reference to organized religion" [7].

Secularization has apparently influenced Western educational systems which are implicitly secular, in some cases more overtly so than in others. Since educational reform has underpinned a curriculum that is based on the sciences and teaching reconceptualized as a scientific activity, scientists were loath to allow theological speculation to interfere with empirical and sensory observation and, as a result, therefore, RE is seen as not fitting into this educational venture and as a consequence religion has no meaning to such an enterprise. At the same time, pedagogical insufficiencies in the subject of RE have not helped matters and have given arguments to opponents who reject theological ideas and are mechanistic and materialistic in condemning $\mathrm{RE}$ for indoctrinating, and nurturing in religion and instructional catechesis.

In spite of this tendency, RE remains within the schooling system in most European countries. It is influenced not only by the idea of secularity, but also by the extent of the secularization of the State which determines the type of RE (confessional, nonconfessional, inter-religious etc) wherever it exists. Thus, RE has been influenced by the historical context and experiences in each country and so is, in each situation, confessional (Germany (partly), Ireland, Spain, Lithuania, Romania, Hungary, Austria, Belgium, Bosnia-Herzegovina, Serbia, Slovakia, Portugal, Italy, Croatia, Poland, Turkey, Cyprus and Malta) or non-confessional (England, Wales and Scotland, Iceland, Norway, Sweden, Finland, Denmark, Netherlands (partly), Switzerland, Moldavia, Greece, Estonia and Latvia), compulsory (Greece, Cyprus, Turkey, Romania, Serbia, Finland, Sweden, Norway, Denmark, Germany, Belgium, Ireland, Iceland, England, Wales and Scotland) or optional (Malta, Croatia, Italy, Hungary, Moldavia, Russia, Estonia, Poland, Netherlands, Spain and Portugal). In some countries different curricula exist and so the content of the subject is partly confessional or in some cases there are different approaches or optional subjects according to the region of the country or the type of the school. Furthermore, there are countries that are committed to a strict separation of religion and state, where RE does not feature as a subject in the curriculum (France, Albania, Ukraine, Belarus and Slovenia) [8].

\section{The compulsory RE}

$\mathrm{RE}$ is related to factors such as family tradition, the cultural environment, the religious community, political perspectives and the age of the student. All the above articulate the idea that in European societies great cultural and religious pluralisation exists and it is an ongoing procedure. The radical transformation of our society highlights the need for new solutions in order to ensure that different people with different religious, cultural and political backgrounds can live together and enter into a dialogue of mutual respect and understanding. In education these differences can be addressed without creating conflict or exclusion. In education moreover, people can learn about religion in general as a human phenomenon, about their own religion if they have one, as well as others' religions and beliefs. Moreover, in education students can re-think and re-read religious ideas, texts and events by individual and groups. All European citizens have to have religious literacy and be able to apply critical thinking to their religious knowledge.

The arguments on both sides, for a compulsory RE or not, are associated exactly with the above but they shed light from a different angle.

Firstly, those who prefer RE to be out of the curriculum argue about privacy. Their main contention is that religious beliefs are personal and too sensitive to be dealt with in the schooling system. Moreover, as teachers have their own beliefs, they consider that it is impossible to avoid influencing their presentation of religions in the classroom. So "the simplification involved will necessarily stereotype traditions and be likely to represent them, differences between pupils will be stressed in a way that could cause trouble, and it is better to stress the sort of human moral values which can be shared by all traditions and none rather than values which divide us" [Cush 5]. Religious people, however, are in the minority according to their point of view and there is no reason for the vast majority of the population to be taught a subject for so many years with content relevant only to small number of people [9]. Finally, there are those who believe that religion has to be excised from the curriculum hence religions have a negative impact on society and human life and, moreover, all religious traditions are considered as completely false. How, then, can education that is based and focused on scientific evidence and method embrace a subject with such content?

On the other hand, the advocates of the confessional RE believe that within education people have to firmly establish their own identity, first by their family values and secondly by their nation's or their countries religious and moral values. Of course one religion or one particular faith contains the whole truth for them and children's education has to 
contain it because it is important to their lives. Furthermore, countries with dominant or prevailing religions, such as Greece, consider RE to be an important factor in national civic cohesion.

Above all, the advocacy for compulsory RE relies basically on the arguments for a non-confessional RE which is considered as an open-ended educational process that does fair justice to religious pluralism whilst providing religious literacy and supporting students in developing their cultural identity by teaching the world's religions and other worldviews.

Firstly, it is impossible nowadays to understand contemporary issues, problems and human culture without knowledge of the religious plurality which is a factor that makes the interpretation of the phenomena more difficult exactly because a variety of traditions, religious and philosophical, exist. Educational scope is maintained by exploring within and across faiths, enabling students to learn different religions, beliefs, traditions and values, and their influences on individuals, societies, communities and cultures. Some results of the REDCo -Project (covering 8 European countries) underline the importance of religious literacy which is one of the main aims of education in the post-modern era. Teenagers' perspectives on the role of religion in their lives, schools and societies illustrate that: 1) Religious pluralism is not only accepted, but welcomed by the students, 2) Students expressed criticism against truth claims that exclude people of other religions or world views and 3) In spite of the awareness of the conflicts caused by religions and the difficulties arising from religious plurality, the majority of students appeared to share a vision of peaceful coexistence in a religiously plural society [10]. Secondly, school is the main recourse and an actual safe environment for learning about religions and religious perceptions of other students, especially for those who have no commitment to one religion or others who are atheists. Besides for those who are members of a religious community, the school provides the main opportunity to come into contact with other religions and beliefs. Thus school offers unique possibilities to promote students' understanding, communication, tolerance and respect between and towards each other encouraging students to reflect on, analyse and evaluate their beliefs, values and practices and communicate their responses. REDCo research revealed a trend among youngsters that may be considered as important. It says that most students in Europe would like school to be a place for learning about religion and worldviews, rather than for instruction in a particular religion. Another independent qualitative and quantitative research which was conducted by the author in the period of 2006-2009 in different regions of Greece using qualitative interviews and discussion in focus groups (age 15-24) holding three meetings for each group in one year, reveals the same topics and stresses that: most young people learn about their religion and other religions within the school system $(72 \%$ out of $n=356)$ and only a few $(15 \%)$ from the Church. Obviously the fact that young people who believe in one religion (Christianity in this case) do not learn about it from their religious community is something that makes the religious community worried about the future of religion. On the other hand the research stresses the role of school and RE in their lives and societies. Furthermore the research reveals that most young people want to know more about each other's religions and worldviews (77\%), and most prefer school to be the place for learning about religions and worldviews $(71 \%)$ and only a few for it to be a place for instruction in only one particular religion (17\%). Moreover, many admit that the content of RE has turned out to be useful in their lives and their understanding of not only of current world events but also related to personal issues $(60 \%)$ [11].

Table 1. Database contexts Young people's perspectives for RE in Greece

\begin{tabular}{|l|l|}
\hline \multicolumn{2}{|l|}{$\mathrm{N}=356$} \\
\hline $\begin{array}{l}\text { Learn about their religions and the other } \\
\text { religions within the school system }\end{array}$ & $72 \%$ \\
\hline $\begin{array}{l}\text { Learn about their religions and the other } \\
\text { religions from the Church }\end{array}$ & $15 \%$ \\
\hline $\begin{array}{l}\text { Want to know more about each other's } \\
\text { religions and worldviews }\end{array}$ & $77 \%$ \\
\hline $\begin{array}{l}\text { Prefer school to be a place for learning about } \\
\text { religions and worldviews }\end{array}$ & $71 \%$ \\
\hline $\begin{array}{l}\text { Prefer school to be a place for instruction into } \\
\text { one particular religion }\end{array}$ & $17 \%$ \\
\hline $\begin{array}{l}\text { Admit that the content of the RE has turned } \\
\text { out to be useful for their lives and their } \\
\text { understanding not only of current world events } \\
\text { but also of personal issues }\end{array}$ & $60 \%$ \\
\hline
\end{tabular}

In addition, findings of another Greek research project are relevant to the trends above. The research was conducted in the Pedagogical faculties at seven Greek Universities through the completion of 1009 questionnaires about RE. The participants were all students and future teachers who will teach RE in Greek and Cypriot primary schools. Among the trends that emerged from the data, what is important for compulsory RE is that the majority of the students believe that RE is very necessary for public schools (55\% out of $n=1009)$ and the content of RE has to be a study of the religious phenomenon (45, $09 \%$ ), religions of the others $(31,02)$, and one religion, Christianity in particular (20,02\%). Moreover a significant majority of them $(82,46 \%)$ believe that a RE teacher can teach RE regardless of being or not being a member of a religious community but just under half of them $(47,08 \%)$ admit that an atheist or a non-religious student can't attend a compulsory RE lesson even if this is inter- 
religious. It may be that research reveals that in the perspectives of future teachers RE still has a relation to the Church and obviously this is an actual discrepancy between what they say about RE $(72,35 \%$ believe that it is an integral part of school's citizen education while $79,98 \%$ that it boosts tolerance towards diversity) and what they stereotypically believe [12].

Thirdly, all youngsters, according to the Universal Declaration of Human Rights (article 2 guarantees the right to those of all religions, article 18 demands freedom of thought, religious belief and practice and article 26 articulates the right to education) have the right to an education that promotes understanding and tolerance between national, racial or religious groups. That means that RE's exclusion from education undermines children's right to an education that provides knowledge and ideas to further students understanding of their societies and the role of religions in the contemporary world [13]. Of course parents have to be responsible for the upbringing and development of the child (article 18.1), but it is still the state's responsibility to ensure that all citizens are educated. As far as RE is concerned, it is the state's responsibility again to promote RE that would be a help for all parents and not a cause of problems.

Moreover, the European Convention of Human Rights maintains that "everyone has the right to freedom of thought, conscience and religion; this right includes freedom to change his religion or belief and freedom, either alone or in community with others and in public or private, and to manifest his religion or belief, in worship, teaching, practice and observance" (article 9.1) but that "freedom to manifest one's religion or beliefs shall be subject only to such limitations as are prescribed by law and are necessary in a democratic society in the interests of public safety, for the protection of public order, health or morals, or for the protection of the rights and freedoms of others." (article 9.2).

Besides in the European area there has been a dialogue for inter-religious and intercultural education since 2001. A project on teaching religions in school was launched in 2002 and it argued that regardless of the truth or the falsity of each religion, religion is an integral part of life and culture. Therefore, religion should be understood by all citizens as part of their education. The Committee of Ministers agreed to a policy recommendation (CM/Rec (2008)12) that all member states should include the impartial study of religions within the curricula of their school's systems. This recommendation which incorporated ideas from the White Paper on Intercultural Dialogue, gives a compelling cultural argument for the study of religions and legitimacy for a compulsory RE. It should be mentioned that its principles provide the intercultural dialogue and its dimension of religious and non-religious convictions as significant factors for the development of tolerance and cultural coexistence. Among its objectives are: nurturing a sensitivity to the diversity of religions and nonreligious convictions as an element contributing to the richness of Europe, ensuring that teaching about the diversity of religions and non-religious convictions is consistent with the aims of education for democratic citizenship, human rights and respect for equal dignity of all individuals and promoting communication and dialogue between people from different cultural, religious and non-religious backgrounds [14]. Of course, when somebody speaks in favour of compulsory RE in Europe, one has to bear in mind, moreover: 1) the Toledo Guiding Principles on Teaching about Religions and Beliefs in Public Schools (a result of Organization for Security and Cooperation in Europe- OSCE based in Vienna) which was produced in 2007 and it is an essential tool for the study and the knowledge about religions and beliefs at schools, based on the rationale of religious freedom [15] and 2) the recommendation 1720/2005 which was adopted by the Committee of Ministers in 2006 (965th meeting/24-5-2006) that encourages the governments of member states to ensure that religious studies are taught at the primary and secondary levels of state education. Furthermore, the recommendation addresses: 1) that the aim of this education should be to make pupils discover the religions practiced in their own and neighboring countries, to make them perceive that everyone has the same right to believe that their religion is the "true faith" and that other people are not different human beings through having a different religion or not having a religion at all, 2) it should include, with complete impartiality, the history of the main religions, as well as the option of having no religion, 3) it should provide young people with educational tools that enable them to be quite secure in approaching supporters of a fanatical religious practice, 4) it must not overstep the borderline between the realms of culture and worship, even where a country with a state religion is concerned. It is not a matter of instilling a faith but of making young people understand why religions are sources of faith for millions (article 14) [16]

Of course, all the documents set out the criteria for a $\mathrm{RE}$ for all children regardless of their religion or non-religion and human rights remain the bedrock of each policy of Council of Europe [17].

\section{Pedagogical approach to a compulsory RE}

Today, variability exists in RE pedagogical approaches. But a compulsory RE, based on the criteria of the legislation above and the scientific findings which are mentioned should be a postmodernist approach. This means that RE 
emphasizes the development of attitudes and skills required to deconstruct and debate objective knowledge. Argument and subjectivity are valued and authority is contestable and negotiable. Moreover the engagement with particular ideas, persons, events and texts is open to interpretation and re-reading by individuals and groups. The closest to a postmodern position is the constructivist threestage approach to RE of Michael Grimmitt [18] and others, who expanded his work on pedagogical strategy, such as Clive Erricker whose five-stage pedagogical approach is proving an effective way for $\mathrm{RE}$ teachers to relate constructivist theories to the different realities of classroom practice [Erricker 6].

The pedagogical implications of applying the constructivist theory of learning may be summarized as follows: Students learn through 1) enquiry, interaction and reflection, 2) making links between the religious content of the lesson and their own experiences, needs and beliefs, 3) constructing their own meanings and drawing their own conclusions, 4) being challenged by the standpoints of the others and responding to the learning opportunities that are offered by the teacher or the other students, 5) engaging in collaborative and co-operative actions, 6) reflecting critically on their own knowledge, belief and value assumption and constructing new meanings [19].

More importantly, this approach engages students in co-inquiry. They can acquire knowledge with even greater benefits as members of a learning community developing the reflexive knowledge of self, each other and the subject of RE [17]. This learning would be inclusive in terms of belonging or unbelonging. Moreover it would be pluralist, respecting and being constructed on the personal experiences and cultural/religious knowledge each learner brings. But learners not only become the creators of knowledge and skills but also become capable of learning as they proceed, by collaborating, innovating, and being creative and flexible. This kind of person would a believer but without any fear of critique and change [20].

The three or five -stage pedagogical process of Grimmitt and Erricker, placing a pedagogic emphasis on the development of the learner, using a specific constructivist theory, illustrates a clear grasp of how RE can be situated within what is an overall secular educational environment and make a distinctive contribution to RE pedagogy and to religious studies in general.

\section{The right to withdraw from $\mathrm{RE}$}

A compulsory RE for all as it is articulated above has limited possibilities for withdrawal. It is obvious that a catechetical RE increases the possibilities that some parents who decide to withdraw their children from RE may through this withdrawal be said to leave their children open to a stigmatizing effect thus making the children vulnerable to teasing and bulling [21]. Therefore withdrawals have to be justified (mentioning specifically particular reasons) by the parents and to be few in number. A pluralistic and objective RE for all children, whatever their background, wherein all the children learn together as a 'learning community' about their heritage and about all religions and secular world views may limit the withdrawals though anyone can deny at least the right of withdrawal. Significant data is provided by Norwegian history and the practice of RE and their experience in withdrawals policies and in the possibility to create a subject that satisfies human rights for all [22].

\section{Conclusion}

Research and experience demonstrates that RE should be compulsory in public schools provided it responds to contemporary pedagogical principles and to the increasing impact of religious plurality.

As has been mentioned the content of the subject and the pedagogical approach to it should be a postmodern endeavour including a variety of religious and non- religious beliefs, interdisciplinary enquiry and above all be of relevance in relation to students' lives. An effective RE will not occur unless the professional educator finds a way to deal with the differences in the classroom and of course the different religions and beliefs.

Unfortunately in RE academic society not many pedagogical researches have been conducted or their findings published that are well-known. English and some Scandinavian practices and experiences are the only known ones and that means that new researches need to be conducted on different implementations in a variety of religious and secular educational environments. Besides almost nothing has been published for RE practices and researches from those European countries in which Othodox Christianity is dominant e.g. Russia, Romania etc.

As a matter of fact international legislation and innovative approaches to learning and RE learning allow us to conclude that in this way RE could be a compulsory subject within the curriculum and this might contribute to education in these countries. That means that RE should only be the State's responsibility and, all religious communities should only have an advisory role.

As a first step to changing or making interventions in RE in Europe it is useful to construct a European consensus regarding $\mathrm{RE}$ based on a platform of previous European experience, rationales for studying, particular policies and standard-setting policy recommendations.

A development has arisen, an example of which is REDCo research that proves that religion (we don't speak about God) is back. Therefore, post- 
modern, future citizens have to acquire for their own welfare religious literacy. They will be able to be critical religious believers, if they want to and active members in society respecting and tolerating 'others'. RE may be a networking factor in society and a guiding metaphor for students' lives in which 'we' is the guide. Instantly, in this ferocious postmodern era the hope for 'we' is revealed: humanly interconnected, discerning, agile and flexible.

\section{References}

[1] P. Berger, "Protestantism and the Quest for Certainty", The Christian Century, Christian Century Foundation, Chicago, August 26-September 2, 1998, pp. 782-796.

[2] Berger, P., The Social reality of religion, Penguin University Books, Middlesex, 1973.

[3] P. Berger, "Some second thoughts on Substantive versus Functional definition of Religion", Journal for the Scientific Study of Religion, Wiley-Blackwell, 1974, 13:2, pp.125-133.

[4] Said, E., Orientalism, Pantheon Books, New York, 1978.

[5] D. Cush, "Should religious studies be part of the compulsory state school curriculum?", British Journal of Religious Education, Routledge, London, 2007, 29:33, pp. 217-227.

[6] Erricker, C., Religious Education, Routledge, London and New York, 2010.

[7] A. Wright, "The justification of compulsory religious education: a response to Professor White, British Journal of Religious Education, Routledge, London, 2004, 26:2, pp. 165-174.

[8] Lähnemann, J. and P. Schreiner (Edit.), Interreligious and Values Education in Europe, PESC-Comenius Institut, Münster, 2009.

[9] J. White, "Should Religious Education be a compulsory school subject?", British Journal of Religious Education, Routledge, London, 2004, 26:2, pp. 151-164.

[10] Valk, P., G. Bertram-Troost, M. Friederici, C. Béraud (Edit.), Teenagers' perspectives on the role of religion in their lives, schools and societies, Waxmann, Münster, 2009.

[11] Koukounaras-Liagis, M., Order and Disorder, Akritas, Athens, 2011.

[12] Karamouzis, P. and E. Athanasiadis, Religion, Education. Post-modernism, Kritiki, Athens, 2011.

[13] C.Evans, "Religious Education in public schools: an international human rights perspective", Human Rights Law Review, London, 2008, 8:3, pp. 449-473
[14] Council of Europe, Recommendation $\mathrm{CM} / \operatorname{Rec}(2008) 12$ of the Committee of Ministers to member states on the dimension of religions and nonreligious convictions within intercultural education. https://wcd.coe.int/ViewDoc.jsp?id=1386911\&Site=CM accessed 1 July 2012]

[15] OSCE, the Toledo Guiding Principles on Teaching about Religions and Beliefs in Public Schools, OSCE, Warsaw, 2007, http://www.osce.org/node/27217 accessed 1 July 2012]

[16] Council of Europe, Recommendation 1720/(2005) of the Parliamentary Assembly about Education and Religion. http://assembly.coe.int/Documents/AdoptedText/ta05/ERE C1720.htm accessed 1 July 2012]

[17] R. Jackson, "European developments" in L.P.Barnes (Edit.), Debates in Religious Education, Routledge, London and New York, 2012, pp.168-179.

[18] Grimmitt, M. (Edit.), Pedagogies of Religious Education, McCrimmons, Great Wakering, 2000.

[19] M. Grimmitt, "Constuctivist Pedagogies of Religious Education project: RE-thinking Knowledge, Teaching and Learning in Religious Education” in M.Grimmitt (Edit.), Pedagogies of Religious Education, McCrimmons, Great Wakering, 2000, pp.207-227.

[20] V. Baumfield, "Pedagogy" in L.P.Barnes (Edit.), Debates in Religious Education, Routledge, London and New York, 2012, pp.205-222.

[21] Kalantzis, M. and Cope, B. New Learning, Cambridge University Press, New York, 2012.

[22] Hagesæther, G. and S. Sandsmark, "Compulsory Education in Religion-the Norwegian case: an empirical evaluation of RE in Norwegian schools, with a focus on human rights", British Journal of Religious Education, Routledge, London, 2011, 28:3, pp.275-287. 